\title{
The Effect of Halal-Labelled Food Awareness Towards Purchase Intention Among Urban Muslims (Study of Indonesian Students in Japan)
}

\author{
Yoga Fadhil Nurfajri ${ }^{1 *}$ \\ ${ }^{1}$ Padjadjaran University, Bandung, Indonesia
}

\begin{abstract}
The objective of this research is to investigate the effect of halal-labeled food awareness towards purchase intention of Indonesian Muslim student in japan. Survey data obtained from 101 Indonesian students from all over Japan and was analyzed with descriptive and verification methods, whereas SMART-PLS was utilized for hypothesis testing. In this research, halallabelled food purchase intention variable was derived from Alam \& Sayuti (2011) and Bone et al (2007). The result showed that all of halal-labelled food awareness influence Indonesian Muslim student purchase intention, with perception toward halal certification variable was the most significant factors for halal-labelled food awareness and perceive behavioral control as the most significant factor which influence halal-labeled food purchase intention. The limitation in this researched is the data was obtained through online questionnaire and using snowball sampling method, this method may cause bias since author was unable to control the spreading of the questionnaire and people who did not meet the criteria to fill the questionnaire may filled it.
\end{abstract}

Keywords: Halal awareness, halal-food, Islamic marketing, Japan, purchase intention.

\section{INTRODUCTION}

Halal is derived from Arabic with literal meaning permissible or allowed, which means all of the things that allowed to consume, to wear, and to do (related to worship) under sharia rule. In the Quran every food is categorized halal until those that are mentioned as haram (prohibited or unlawful to consume) such as pork, blood, corpse and etc. Consuming halal food for Muslim is not an alternative but a dietary standard prescribed in Quran that they must follow anywhere and anytime as it does with Kosher dietary standard for Jew and vegan dietary for Hindu. Hence halal food industry become one of the developed and the biggest religion-prescribed dietary in the world with million consumers per day.

* Corresponding author. Email address: yogafadhill@gmail.com 
Halal food industry is one of the biggest food industry in the world with a market size of US\$ 1,245bn in 2016 (Thomas Reuters 2016). Meanwhile, the total global spend for food on 2016 was reached US\$ 7,323bn which mean that Muslim consumption for halal foods \& beverages contributed $17 \%$ of global consumption. With a steady growth of Muslim population, this number is expected to grow into 1,930 Billion US\$ in 2022. This number was not a surprise since Muslim population is accounted for $23.2 \%$ of total world population.

In country like Indonesia where Muslim is a majority group the general problem is how to know the genuineness of their halal food, moreover in this modern era where foods and beverages were made and packed behind closed door. As a consumer that must ensure halal-ness of the food, modern Muslim has heavily relied on the halal certification given by scholar or designated organization to decide which food they could consume. Meanwhile, in a Muslim minority country such as Japan., the awareness of halal food and the availability to purchase halallabelled food has been happening as a problem for years.

Japan is a developed country which become one of the most popular destination to study for Indonesian student. There are approximately 5,495 Indonesian students in Japan, this number was increased $18.7 \%$ from last year (JASSO 2017) and will more likely increase in the upcoming years. In addition, Japan was ranked $5^{\text {th }}$ as the most popular study destination for Indonesian student by UNESCO.

Besides its status as a developed country, Japan has a lot more to offer such as its lifestyle, numerous scholarship provided both by the government and private companies, and popular Japanese culture.

Even though Japanese culture are admired and known by many Indonesian youth it is just a tip of the iceberg. As a country with a different root with Indonesia that has less than 1\% Muslim of its total population, Japan's culture and lifestyle become a double-edged sword for Indonesian students who live in Japan. It would widen their perception, but on the other hand, they would experience more hardship to perform religious practices since Islam is still considered as an alien religion by most Japanese who is having lack of interest to know about it.

The implication of apathy towards Islam in Japan has led to a tougher time for Muslim to fulfill their religious duties, hence, Muslims often find that it is not that easy to travel or live while keeping their belief and consuming only Halal foods (Adidaya, 2016) especially for packed or canned food, which may cause their awareness of halal food decrease. A packed halal-labelled food is still limited in term of variety and availability, only certain shops that sell halal-labelled food such as Asian stores and Muslim stores with relatively higher price.

It has been discussed that halal-labelled food is uncommon in Japan both the variety and availability. Regarding to those problem writer is curious to know whether Indonesian Muslim student still has good awareness for halal-labelled food and intention to purchase it, since doing it need extra effort and money.

\section{LITERATURE STUDY/HYPOTHESES DEVELOPMENT}

Awareness on buying and consuming halal food is important for every Muslim, moreover in this globalization era where food product is ranging from A to $\mathrm{Z}$. The consequences of consuming non-halal food are harmful to our body and the worst thing is that the prayer (ibadah/shalat) that we performed will not be 
accepted by Allah. In Indonesia, as a Muslim majority country, finding halal food is effortless even we can assume that most food is halal due to the seller, but on the other hand, in a country where Muslims are minority such as in Japan, finding halal food can be quite challenging since the availability and exposure of halal food are limited. But no matter how hard it is, we must always aware the existence of halal food around us because it is important for Muslims to have an understanding and knowledge on what Halal is all about in measuring Halal awareness (Yunus et al, 2014).

According to Randolph (2003), awareness means the knowledge of some subject or situation. In halal context, it also means having special interest in or experience of something and/or being well informed of what is happening at present time on halal food, drinks, and product. Furthermore, Ambali \& Bakar (2014) stressed out that awareness is a relative concept where a person may partially, subconsciously, and acutely aware of an issue relating to halal aspects.

In this paper, the variable used to measure halal food awareness by Ambali \& Bakar (2014) will be utilized to measure halal-labelled food awareness for Indonesian student in Japan. There are 4 variables used, namely religious belief, perception toward halal certification, exposure and health reason. Religion and belief are sources of awareness towards consumption behavior and the best guideline to determine the food consumption Ambali \& Bakar (2014). Perception toward halal certification becomes essential since it will directly alter people awareness on halal-labelled food and help them decide its importance. Exposure measure how they get informed or be exposed about halal-labelled food and how strong it is. Health reason: It is not only religious motives that can determine people awareness towards halal food or products for consumption, but also health issues related to religious identity and degree of acculturation in whatever we consume daily (Bonne et al, 2007). It can be said that it's not only the source of food that become the concern of muslim dietary but also the healthiness which becomes the reason why people aware of the existence of halal food.

There are two theories which commonly served as a theoretical basis for explaining purchase intention namely AIDA (awareness, interest, desire, and action), TPB (Theory of Planned Behaviour). AIDA is the oldest and the most popular marketing model that commonly use to capture consumer response toward the product. In principle, the idea of AIDA is to affect consumer awareness until they buy the product through several steps. Schaefer, Parker, \& Haytko (2011) used AIDA for their research about Chinese and U.S. consumers' perceptions of the effectiveness of celebrity athlete endorsers. Meanwhile, TPB was developed by Ajzen (1991) which relates to three factors or conceptually independent determinants of purhase intention, namely: 1. Attitude, 2. Subjective norm, 3. Perceive Behavior control. In this paper, a modified TPB with an extension model to capture the influence of the cultural and more specific religious context in which halal-labelled is consumed is investigated, as used by Bonne, et, al (2007) which are self-identity, and dietary acculturation will be utilized as the predictors to measure purchase intention, since The TPB model could explains if an individual's performance of a certain behavior is determined by his or her intent to perform that behavior (Alam \& Sayuti, 2011).

TPB has also become the basis for several studies on consumer food choices (Sparks and Shepherd, 1992; Conner and Sparks, 1996; Karijin et al., 2007, Alam \& Sayuti , 2011) and even cosmetics. Bonne, Vermeir, Blackler, \& Verbeke, 
(2007), used the TPB as the basis of their theoretical model to measure halal meat consumption in France. Kim \& Chung (2011) used TPB to measure purchase intention for organic cosmetics.

The variables utilized in this paper is based on classical TPB by Alam \& Sayuti (2011) with an extension model in the context of religion and migration (Bonne, et, al 2007). Attitude may be defined as a degree to which a person has favorable or unfavorable evaluation or appraisal of the behavior in question Alam \& Sayuti (2011). Based on expectancy-value model, the total set of accessible behavioral beliefs which links the behavior to various outcomes and other attributes are important driving factors of attitude toward behavior. Subjective norm definition is suggested by Alam et al (2011) who saw it as a perceived social pressure to comply with expectation about engaging in the behavior which should influence the individual's intention to perform or not to the behavior. The term subjective norm is used here to refer to the perceived social pressure that influences consumers' decisions to purchase halal food. The term PBC encompasses two aspects: 1) how much a person has control over behavior, 2) how confident a person feels about being able to perform or not perform the behavior Alam \& Sayuti (2011). The more control of an individual about making halal food purchases, the more likely he or she will do so. In this paper, the term that will be used to describe this phenomenon is the ability to purchase halal food. The term habit has been used to refer to situations in which a behavior has become automatic and is beyond an individual's awareness Bonne et al (2007). Previous studies by Biddle (1987) cited in Bonne et al (2007) mostly defined self-identity as a label that people use to describe themselves. It is assumed to be the result of social interaction and the cause of subsequent behavior. The term dietary acculturation is defined as the process that occurs when members of a minority group adopt the eating pattern or food choices of the host culture (Negy and Woods, 1992; Satia et al., 2000).

\section{RESEARCH METHODOLOGY Methodology}

Exploratory research methodology is utilized for this paper, according to Aaker, Kumar, Day dan Leone (2011:72) exploratory is used when one is seeking insights into the general nature of a problem, the possible decision alternatives, and relevant variables that need to be considered. More specifically, descriptive research and verification research with quantitative approach will be utilized in this research. To find the correlation between variables surve methodology will also be utilized in this research.

According to Aaker, Kumar, Leone, \& Day (2011), descriptive research objective is to provide an accurate snapshot of some aspects of certain product condition. Descriptive research is also utilized to better describe the characteristics of a population or studied phenomena to yield a clearer explanation result related with halal food awareness effect on halal food purchase intention.

The verification research or correlational research aims to examine and reveal the clarity of the relationship of variables as well as the correlation which exists between the variables studied, in this case, to learn the effect of halal food awareness on purchase intention. 


\section{Variables measurement}

For determining the dimension of both independent $(\mathrm{X})$ and dependent (Y) variables for operating variables, several previous researches were used as a referenced. Dimensions for halal food awareness

(X) is derived from Ambali, A \& Bakar (2014), meanwhile for purchase intention $(\mathrm{Y})$, the dimensions are referring to classical component of marketing TPB's purchase intention from Alam and Sayuti (2011) and Bonne, et, al (2007). All items intended to measure the variables in this study are adopted from previously validated instruments

Semantic differential (SD) with zero to ten scales are utilized as the measurement scale for this paper. SD is one of the most accurate measurement tools for measuring outcomes emotional feedback from respondents. According to Strungă (2014) semantic differential was developed for measuring social sentiments and attitude with profound consequences for the social research. With semantic differential, people's reactions are measured to determine the stimulus of words and concept in terms of rating on bipolar scales. It is defined with contrasting adjectives at each end.

Halal-labelled food awareness consist of four variables with thirteen indicators/measurements and measured by using 1-10 semantic differential measurement scale. Religious belief construct consists of: The fulfillment of religious duties, Commitment not to eat non-halal food, and Consequence of eating non-halal. Perception toward halal certification are made of: Halal certification knowledge, Halal certification urgency, Halal certification importance, and Product attraction. Exposure: Socialization/advertisement, Access to information, Family as the source of exposure, and friend as the source of exposure. Last but not least Health Reason: Healthy option/reason, Hygiene Option/reason, and Disease prevention.

Meanwhile purchase intention variables are referring to Alam \& Sayuti (2011) and Bonne, et, al (2007) purchase intention variable which consists of six variables with twelve indicators or measurements and is measured by using 1-10 semantic differential measurements scale. Attitude towards halal labeled food construct consists of: "Interest to consume halal food, favorable-unfavorable decision to consume, and Right-wrong decision to buy". Subjective norm constructs were measured with measurement from Venkatesh and Davis (2000) on 1-10 semantic differential measurements scale which consist of: "Motivational to comply, and Social perspective". Perceive Behavior Control was measured with measurements from Taylor and Todd (1995) on 1-10 semantic differential measurements scale consists of: "Ability (financially) to purchase halal food, Knowledge to purchase halal food, Ability to consume halal food, and Knowledge to consume halal food". Habit variables was measured with measurement from (Verplanken and Orbell, 2003; Honkanen et al., 2005; Bonne et, al., 2007) on ten scale semantic differential with indicator "Likeliness to purchase halal food". SelfIdentity was measured by using indicator "Self-identification as Muslim" on ten semantic differential scale (Sparks and Shepherd, 1992; Povey et al., 2001; Robinson and Smith, 2002). For Dietary Acculturation indicator, respondents were asked their "Preferred food type" on the semantic differential scale from Indonesian cuisine or Japanese cuisine. High score means higher dietary acculturation or the more accustomed someone with their local cuisine in migrated area. 


\section{Sample and Data}

For this study, nonprobability sampling (purposive sampling) will be used as research technique and the data were gathered through primarily data collection method through personally administrated questionnaires and snowball sampling. This method is chosen because it is the most feasible alternative, due to the constraint of speed, costs, conveniences, and especially time in order to obtain enough respondents. Sample criteria which applied for this research were: student that has been live in japan at least for three months, and Muslim with consideration that by living three at least three months (90 days) someone's behaviour has been accustomed with local culture or behavior. Social media such as facebook, and twitter plus a social messenger like LINE, and Whatsapp were utilized to spread the questionnaire. Indonesian Student Association in Japan (Perhimpunan Pelajar Indonesia Jepang), PPI Sendai, PPI Hokkaido, PPI Fukuoka and several Indonesian Youtubers that studied in Japan were among the main respondents and main sites to spreading the questionnaire. In three months period 101 responses were gathered.

\section{Analysis and Design Hypothesis Analysis}

Both descriptive and verification analysis share a number of key features for this research. Descriptive and verification analysis were utilized to better explain the result or phenomena happened in the research. The analysis was done to ensure the quality of the data so that the result generated was accurate. Last but not least, the analysis was done to avoid or at least to minimize bias when interpret the result of the study

Descriptive analysis will be done first or before conducting more complex statistical analysis in this research to get the overview of the data. In addition, descriptive analysis was used to reveal the answer of research question about how halal-labelled food awareness level to purchase intention among urban Muslim. The result would be analyzed towards the interpretation of frequency and percentage score obtained in the form of a sentence to reach conclusion.

Verification analysis was used to measure the relationship between the variables and how strong the relationship between them. Structural equation model method will be utilized, and to determine the better accuracy, Smart Partial Least Square (PLS) 2 software will be utilized. According to Urbach \& Ahlemann (2010, p.12) the purpose of using structural equation model is to confirm the preferred theory used on research.

\section{Model and Design}

Inner model design, outer model design and path diagram are used in this research. Inner model design reflects the relationship between latent variable which based on the substantive of the theory. The design of structural model relationship between latent variable was based on the problem formulation problem or research hypothesis.

The outer model or measurement model defines how each indicator blocks corresponds to its latent variable. The measurement model design will determine the indicators properties of each latent variable, is the model formative or reflective, and based on the definition of the operational variable. 
Path diagram is used as the research prototype of the model. The $\mathrm{X}$ and $\mathrm{Y}$ in path diagram describe or symbolize the number of questionnaire which become the indicator of the variable of this research.

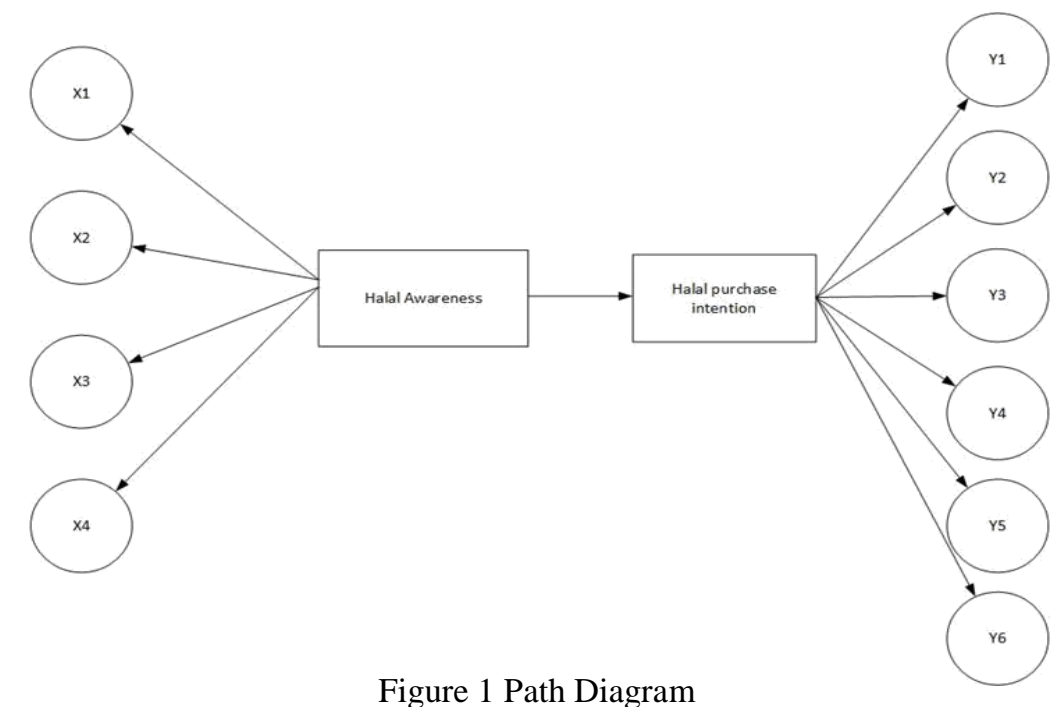

\section{Validity and Reliability}

Model validation denotes the process of systematically evaluating whether the hypotheses expressed by the structural model are supported by the data or not. In general, model validation is an attempt to determine whether the measurement models as well as the structural model fulfill the quality criteria for empirical work, Urbach and Ahlemann (2010, p.18).

To test the data validation, there are several approaches generally used in research. First, Pearson correlation formula is one of the most basic formula to test data validation, below is Pearson correlation formula;

$$
\mathbf{r x y}=\frac{N \sum X Y-\left(\sum X . \Sigma Y\right)}{\sqrt{\left[N \sum X^{2}-\left(\sum X\right)^{2}\right]\left[N \sum Y^{2}-\left(\sum Y\right)^{2}\right]}}
$$

The other test to determine data validity is through factor loading, the easiest way to obtained factor loading value is through SMART-PLS software. The analysis is valid if the factor loading analysis value is 0.5 . If the value is 0.6 it could be categorized as high and if the value is below 0.4 it is categorized as low. The last approach is using Average Variance Extracted (AVE), AVE may be used as a test of both convergent and divergent validity. AVE reflects the average communality for each latent factor in a reflective model. The range value which recommended by Urbach and Ahlemann (2010: 21) for AVE is AVE > 0.5.

\section{Reliability}

Reliability test were conducted to know the consistency of response or answer from respondents, if the result of the questionnaire yields a random answer/point, then the questionnaire might be not reliable (Gozali, 2005). There are two basic approaches currently used to measure reliability; the first one is Cronbach's alpha and the second one is composite reliability. 
Cronbach's alpha technique or formula will determine whether the research's instrument would be reliable or not. According to Sofyan Siregar (2013) a research's instrument could be determined as reliable if the cronbanch's alpha value is higher than 0.6. Meanwhile, composite reliability is generally used as an alternative or amplifier of the result yield by Cronbach's analysis technique. Formulating from Werts et al. and Nunally and Bernstein, internal consistency reliability has a composite reliability for their criterion, attempts to measure the sum of an LV's factor loadings relative to the sum of the factor loadings plus error variance (Urbach and Ahlemann, 2010, p.18). It leads to value between 0 (completely unreliable) and 1 (perfectly reliable). Alternative to Cronbach's Alpha, allows indicators to not be equally weighted. Proposed threshold value for confirmative (explorative) research: CA > 0.700) Urbach and Ahlemann (2010). Values must not be lower than 0.600 .

\section{Hypothesis}

Hypothesis testing will be conducted to test the significances of "Halallabelled food awareness" towards "Halal-labelled food purchase intention". For this research, only T-test (partial test) will be utilized to test the hypothesis.

Hypothesis in this research are as follows:

> H0: There is no significant influence of halal food awareness on halal food purchase intention

> H1: There is significant influence of halal food awareness on halal food purchase intention.

Significant test toward research hypothesis is using t-test with 5\% significant level. With decision making criteria based on probability value (P-value):

o Level of significance $\alpha=0.05$

$\mathrm{O}$ Criteria: Ho is rejected if $\mathrm{P}$-value $<0.05$

Ho cannot be rejected if $\mathrm{P}$-value $\geq 0.05$

According to Malhotra (2010, p.472) the formula of t-test which using only one sample is as follow:

$$
\mathbf{t}=\frac{\dot{X}-\mu}{\frac{S}{\sqrt{n}}}
$$

Where:

$\mathrm{t}=\mathrm{t}$-test coefficient

$\dot{\mathrm{X}}=$ Sample Average

$\mu=$ Population Average

$\mathrm{S}=$ Standard Deviation

$\mathrm{n}=$ Total Sample

To determine whether the hypothesis is accepted or rejected, two-tailed hypothesis testing would be used. According to Sugiyono (2011:97) two-tailed test is used if the null hypothesis (Ho) statement is "equal to" $(=)$ and the alternative hypothesis (H1) statement is "not equal to" $(\neq)$ so that the statement for Ho and H1 respectively is $(\mathrm{Ho}=, \mathrm{Ha} \neq)$. Two-tailed test can be illustrated as the picture below: 


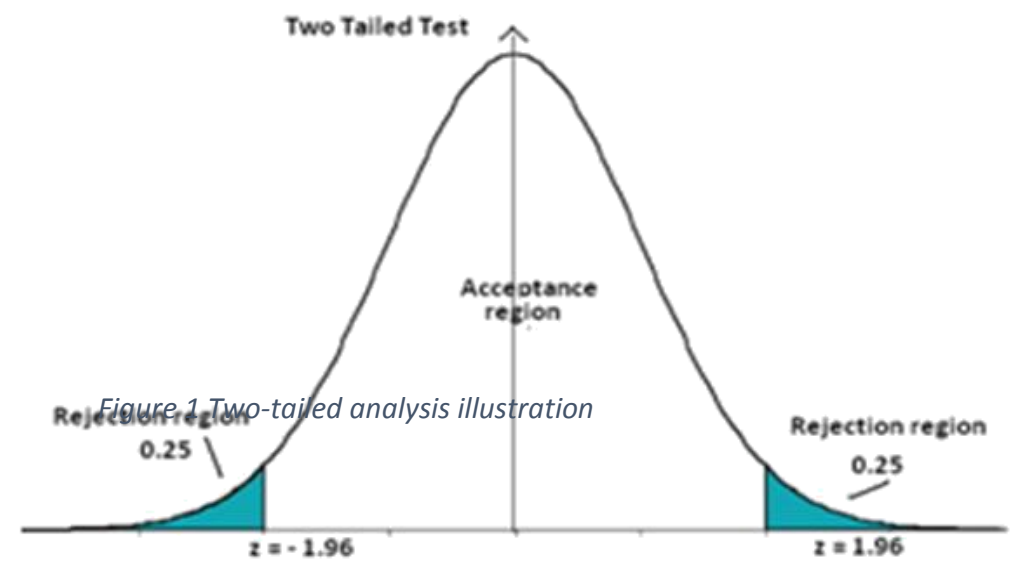

Figure 2 Two-tailed Analysis Illustration

\section{RESULT}

\section{Descriptive Analysis}

A total 106 respondents participated in respondents were excepted from the result due meet the criteria.

The majority of the respondents are male $(51.5 \%)$, the age range of the respondents are 17-32 years old and dominated by people of 23-27 years old (45\%) and followed by people with age group of 28-32 and $>32$ years old respectively $23,7 \%$ and $22,5 \%$. The age range indicated that most respondents were either students of master degree or doctoral degree. Most respondents are living on Kyoto $(10 \%)$, Tokyo (10\%), and Sendai (10\%) which mean that the respondents in this research mostly live in big cities that have numerous halal certificate food shop and restaurants.

The overall result of responds on halal-labelled food awareness was very good with score level of $80.42 \%$. Respondent's perception toward halal certification was really high $(86,2 \%)$ and $96 \%$ of respondents think that halal logo on food was drawing their attention, which indicated that they really care about halal certification on their food. Moving on now to halal purchase intention survey result, in general the survey yield a good result with $77,9 \%$ score among all variables. Attitude towards halal food has the best response with $89 \%$ think it is important.

\section{Structural Inner Model Test}

Reflective model is best suited for this model since in reflective models, indicators are representative set of items which all reflect the latent variable they are measuring. Reflective models assume the factor as "reality" and measured variables as sample of all possible indicators of that reality. This implies that dropping one indicator may not matter much since the other indicators are also representative. The latent variable will still have the same meaning after dropping one indicator (G David 2016).

To determine the significance effects of the indicators to reflect a variable, the t-statistic value must be higher than 1.96 (t-stat > 1.96). Based on the calculation result, most variable shows a value higher than 1.96 which mean that the variables present were significant. 


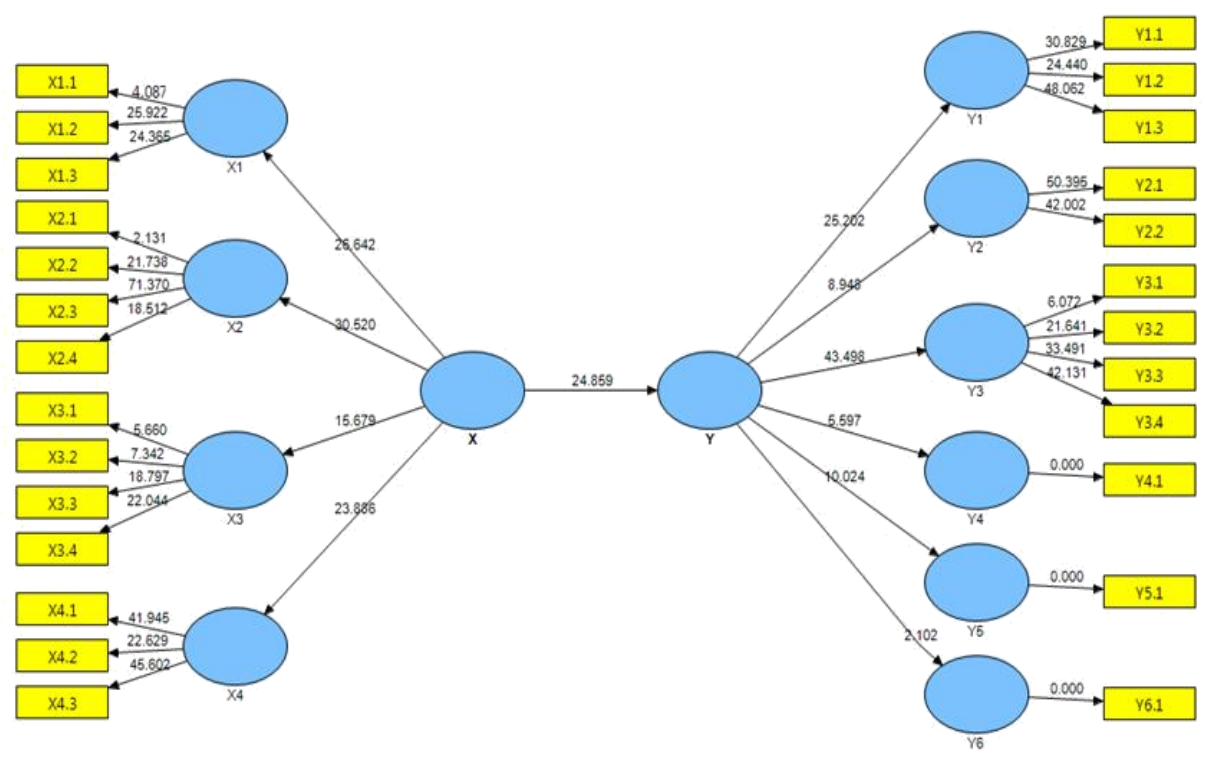

Figure 3 Inner Model SMART-PLS

Table 1 T-stat analysis

\begin{tabular}{|c|c|c|c|}
\hline \multirow{2}{*}{ Validity } & \multicolumn{2}{|c|}{ Test Result } & \multirow{2}{*}{ Explanation } \\
\hline & Effect & t-stat & \\
\hline \multirow{12}{*}{ t-stat } & $\mathrm{X} 1.1<-\mathrm{X} 1$ & 4.087 & \multirow{12}{*}{ Significant } \\
\hline & $\mathrm{X} 1.2<-\mathrm{X} 1$ & 25.922 & \\
\hline & $\mathrm{X} 1.3<-\mathrm{X} 1$ & 24.365 & \\
\hline & $X 2.1<-X 2$ & 2.131 & \\
\hline & $X 2.2<-X 2$ & 21.738 & \\
\hline & $X 2.3<-X 2$ & 71.370 & \\
\hline & $\mathrm{X} 2.4<-\mathrm{X} 2$ & 18.512 & \\
\hline & $X 3.1<-X 3$ & 5.660 & \\
\hline & $X 3.2<-X 3$ & 7.342 & \\
\hline & $X 3.3<-X 3$ & 18.797 & \\
\hline & $X 3.4<-X 3$ & 22.044 & \\
\hline & $X 4.1<-X 4$ & 41.945 & \\
\hline
\end{tabular}


The Effect of Halal-Labelled Food Awareness Towards Purchase Intention Among Urban Muslims (Study of Indonesian Students in Japan)

\begin{tabular}{|c|c|c|c|}
\hline \multirow{2}{*}{ Validity } & \multicolumn{2}{|c|}{ Test Result } & \multirow{2}{*}{ Explanation } \\
\hline & Effect & t-stat & \\
\hline \multirow{14}{*}{ t-stat } & $X 4.2<-X 4$ & 22.629 & \multirow{11}{*}{ Significant } \\
\hline & $X 4.3<-X 4$ & 45.602 & \\
\hline & Y1.1<- Y1 & 30.829 & \\
\hline & $\mathrm{Y} 1.2<-\mathrm{Y} 1$ & 24.440 & \\
\hline & $\mathrm{Y} 1.3<-\mathrm{Y} 1$ & 48.062 & \\
\hline & $Y 2.1<-Y 2$ & 50.395 & \\
\hline & $\mathrm{Y} 2.2<-\mathrm{Y} 2$ & 42.002 & \\
\hline & Y3.1<- Y3 & 6.072 & \\
\hline & $\mathrm{Y} 3.2<-\mathrm{Y} 3$ & 21.641 & \\
\hline & $Y 3.3<-Y 3$ & 33.491 & \\
\hline & Y3.4<- Y3 & 42.131 & \\
\hline & Y4.1<- Y4 & 0.000 & - \\
\hline & Y5.1<- Y5 & 0.000 & - \\
\hline & Y6.1<- Y6 & 0.000 & - \\
\hline
\end{tabular}

\section{$\mathbf{R}^{2}$ and predictive Relevance}

The direct influence of Halal-labelled food awareness (X) toward Halallabelled food Purchase Intention (Y) is $71.8 \%$, while the rest of $28.2 \%$ is influenced by other factors that are not examined. This result shows that the value of $\mathrm{R}^{2}$ is good since the criteria that applied for $\mathrm{R}^{2}$ is the higher the value is preferable (values between 0-1) (Hair et al 2010). Meanwhile, the prediction capability with blindfolding procedure shows that the model of analysis result could explain $71.8 \%$ of data diversity and it is able to observe the phenomenon in research, while $28.2 \%$ was explained by another component that is not observed in this model.

Table 2 R-Square Analysis

\begin{tabular}{|l|l|}
\hline Variable & R-Square \\
\hline Halal-Labelled Food Purchase Intention (Y) & $\mathbf{0 . 7 1 8}$ \\
\hline
\end{tabular}

$$
\begin{aligned}
& \mathrm{Q}^{2}=1-\left(1-\mathrm{R} 1^{2}\right) \\
& \mathrm{Q}^{2}=1-(1-0,718) \\
& \mathrm{Q}^{2}=0,718(71,8 \%) \\
& \text { Galat Model } 100 \%-71,8 \%=28,2 \%
\end{aligned}
$$




\section{Structural (Outer) Model Test}

Outer model specifies the relationship between latent variable with the indicator or variable manifest. Outer model defines how each indicator block corresponds to its latent variable. Below is the figure of the initial model processed using smart pls 2.0 software

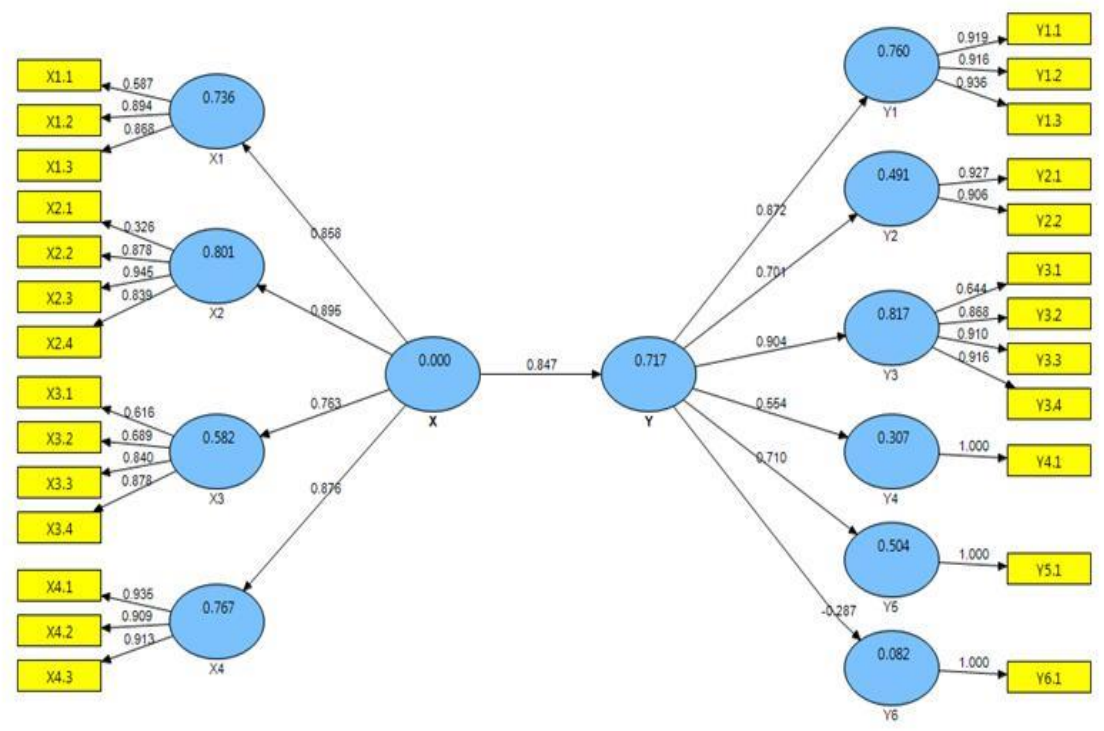

Figure 4 Outer Model SMART-PLS test

\section{Convergent Validity}

The model evaluation could be done by using convergent validity on the reflective model by looking at factor loading value. Factor loading value valid criteria are varies but Hair et al (2010) suggested the value of $>0.5$ but according to Gozali, (2014:24) convergent considered valid indicators, if the value of the loading factor $>0.7$ categorized as high and if 0.5 to 0.6 considered sufficient, by looking at outer loading. In this research, each variable has been categorized as valid and has fulfilled the requirement since the values are $>0.5$ and most of the variable could be categorized as high from all of the indicator, only one indicator that has a value under 0.5 (X2) but those value is still higher than 0.3 , so that indicator is still considered to be remain used in the model. 
The Effect of Halal-Labelled Food Awareness Towards Purchase Intention Among Urban Muslims (Study of Indonesian Students in Japan)

Table 3 Convergent Validity Analysis

\begin{tabular}{|c|c|c|c|}
\hline \multirow{2}{*}{ Validation } & \multicolumn{2}{|c|}{ Result } & \multirow{2}{*}{$\begin{array}{c}\text { Test Criteria } \\
>0.50\end{array}$} \\
\hline & Effect & Factor Loading & \\
\hline \multirow{26}{*}{$\begin{array}{c}\text { Outer Loading } \\
\text { (Convergent } \\
\text { Validity) }\end{array}$} & $\mathrm{X} 1.1<-\mathrm{X} 1$ & 0.587 & Valid \\
\hline & $\mathrm{X} 1.2<-\mathrm{X} 1$ & 0.894 & Valid \\
\hline & $\mathrm{X} 1.3<-\mathrm{X} 1$ & 0.868 & Valid \\
\hline & $\mathrm{X} 2.1<-\mathrm{X} 2$ & 0.326 & Valid \\
\hline & $\mathrm{X} 2.2<-\mathrm{X} 2$ & 0.878 & Valid \\
\hline & $\mathrm{X} 2.3<-\mathrm{X} 2$ & 0.945 & Valid \\
\hline & $\mathrm{X} 2.4<-\mathrm{X} 2$ & 0.839 & Valid \\
\hline & $\mathrm{X} 3.1<-\mathrm{X} 3$ & 0.616 & Valid \\
\hline & $\mathrm{X} 3.2<-\mathrm{X} 3$ & 0.689 & Valid \\
\hline & $\mathrm{X} 3.3<-\mathrm{X} 3$ & 0.840 & Valid \\
\hline & $\mathrm{X} 3.4<-\mathrm{X} 3$ & 0.878 & Valid \\
\hline & $X 4.1<-X 4$ & 0.935 & Valid \\
\hline & $X 4.2<-X 4$ & 0.909 & Valid \\
\hline & $X 4.3<-X 4$ & 0.913 & Valid \\
\hline & $\mathrm{Y} 1.1<-\mathrm{Y} 1$ & 0.919 & Valid \\
\hline & $\mathrm{Y} 1.2<-\mathrm{Y} 1$ & 0.916 & Valid \\
\hline & $\mathrm{Y} 1.3<-\mathrm{Y} 1$ & 0.936 & Valid \\
\hline & $\mathrm{Y} 2.1<-\mathrm{Y} 2$ & 0.927 & Valid \\
\hline & $\mathrm{Y} 2.2<-\mathrm{Y} 2$ & 0.906 & Valid \\
\hline & $\mathrm{Y} 3.1<-\mathrm{Y} 3$ & 0.644 & Valid \\
\hline & $\mathrm{Y} 3.2<-\mathrm{Y} 3$ & 0.868 & Valid \\
\hline & $\mathrm{Y} 3.3<-\mathrm{Y} 3$ & 0.910 & Valid \\
\hline & $Y 3.4<-Y 3$ & 0.917 & Valid \\
\hline & $Y 4.1<-Y 4$ & 1.000 & Valid \\
\hline & $Y 5.1<-Y 5$ & 1.000 & Valid \\
\hline & Y6.1<- Y6 & 1.000 & Valid \\
\hline
\end{tabular}

\section{Discriminant Validity}

The discriminant validity assessment has a goal to ensure that a reflective construct has the strongest relationships with its own indicators (e.g., in comparison with any other construct) in the PLS path model (Hair et al., 2017). Indicator's variable can also be measured by evaluating cross loading (discriminant validity) which shows that the correlation indicator's value in the same variable is better than in the other indicator's variable. The result shows that the squared correlations for each construct is less than the average variance extracted by the indicators measuring that construct. In other words, the measurement model reflects an adequate convergent validity and discriminant validity. 
Table 4 Discriminant Validity Analysis

\begin{tabular}{|c|c|c|c|c|c|c|c|c|c|c|c|c|}
\hline & $\mathbf{X}$ & X1 & $\mathrm{X} 2$ & $\mathbf{X 3}$ & $\mathrm{X} 4$ & $\mathbf{Y}$ & Y1 & Y2 & Y3 & Y4 & Y5 & Y6 \\
\hline X1.1 & 0.386 & 0.587 & 0.287 & 0.214 & 0.273 & 0.304 & 0.128 & 0.341 & 0.296 & 0.180 & 0.227 & -0.242 \\
\hline X1.1 & 0.386 & 0.587 & 0.287 & 0.214 & 0.273 & 0.304 & 0.128 & 0.341 & 0.296 & 0.180 & 0.227 & -0.242 \\
\hline X1.2 & 0.737 & 0.894 & 0.595 & 0.452 & 0.603 & 0.623 & 0.505 & 0.413 & 0.582 & 0.386 & 0.508 & -0.120 \\
\hline X1.2 & 0.737 & 0.894 & 0.595 & 0.452 & 0.603 & 0.623 & 0.505 & 0.413 & 0.582 & 0.386 & 0.508 & -0.120 \\
\hline X1.3 & 0.827 & 0.868 & 0.804 & 0.458 & 0.683 & 0.699 & 0.666 & 0.311 & 0.694 & 0.276 & 0.524 & -0.155 \\
\hline X1.3 & 0.827 & 0.868 & 0.804 & 0.458 & 0.683 & 0.699 & 0.666 & 0.311 & 0.694 & 0.276 & 0.524 & -0.155 \\
\hline X2.1 & 0.253 & 0.132 & 0.326 & 0.221 & 0.157 & 0.312 & 0.318 & 0.198 & 0.316 & 0.108 & 0.149 & 0.088 \\
\hline X2.1 & 0.253 & 0.132 & 0.326 & 0.221 & 0.157 & 0.312 & 0.318 & 0.198 & 0.316 & 0.108 & 0.149 & 0.088 \\
\hline X2.2 & 0.766 & 0.711 & 0.878 & 0.417 & 0.574 & 0.644 & 0.575 & 0.322 & 0.604 & 0.399 & 0.438 & -0.348 \\
\hline X2.2 & 0.766 & 0.711 & 0.878 & 0.417 & 0.574 & 0.644 & 0.575 & 0.322 & 0.604 & 0.399 & 0.438 & -0.348 \\
\hline X2.3 & 0.877 & 0.724 & 0.945 & 0.601 & 0.684 & 0.723 & 0.701 & 0.422 & 0.643 & 0.356 & 0.479 & -0.274 \\
\hline X2.3 & 0.877 & 0.724 & 0.945 & 0.601 & 0.684 & 0.723 & 0.701 & 0.422 & 0.643 & 0.356 & 0.479 & -0.274 \\
\hline X2.4 & 0.746 & 0.617 & 0.839 & 0.489 & 0.563 & 0.671 & 0.672 & 0.323 & 0.656 & 0.180 & 0.459 & -0.190 \\
\hline X2.4 & 0.746 & 0.617 & 0.839 & 0.489 & 0.563 & 0.671 & 0.672 & 0.323 & 0.656 & 0.180 & 0.459 & -0.190 \\
\hline X3.1 & 0.384 & 0.222 & 0.234 & 0.616 & 0.261 & 0.394 & 0.221 & 0.387 & 0.368 & 0.332 & 0.305 & -0.151 \\
\hline X3.1 & 0.384 & 0.222 & 0.234 & 0.616 & 0.261 & 0.394 & 0.221 & 0.387 & 0.368 & 0.332 & 0.305 & -0.151 \\
\hline X3.2 & 0.537 & 0.288 & 0.463 & 0.689 & 0.393 & 0.430 & 0.381 & 0.279 & 0.385 & 0.260 & 0.263 & -0.257 \\
\hline X3.2 & 0.537 & 0.288 & 0.463 & 0.689 & 0.393 & 0.430 & 0.381 & 0.279 & 0.385 & 0.260 & 0.263 & -0.257 \\
\hline X3.3 & 0.649 & 0.452 & 0.469 & 0.840 & 0.484 & 0.491 & 0.452 & 0.376 & 0.385 & 0.230 & 0.447 & -0.133 \\
\hline X3.3 & 0.649 & 0.452 & 0.469 & 0.840 & 0.484 & 0.491 & 0.452 & 0.376 & 0.385 & 0.230 & 0.447 & -0.133 \\
\hline X3.4 & 0.701 & 0.487 & 0.529 & 0.878 & 0.525 & 0.592 & 0.508 & 0.439 & 0.528 & 0.298 & 0.484 & -0.086 \\
\hline X3.4 & 0.701 & 0.487 & 0.529 & 0.878 & 0.525 & 0.592 & 0.508 & 0.439 & 0.528 & 0.298 & 0.484 & -0.086 \\
\hline X4.1 & 0.826 & 0.613 & 0.640 & 0.578 & 0.935 & 0.713 & 0.679 & 0.558 & 0.613 & 0.372 & 0.417 & -0.091 \\
\hline X4.1 & 0.826 & 0.613 & 0.640 & 0.578 & 0.935 & 0.713 & 0.679 & 0.558 & 0.613 & 0.372 & 0.417 & -0.091 \\
\hline X4.2 & 0.774 & 0.610 & 0.603 & 0.464 & 0.909 & 0.629 & 0.673 & 0.479 & 0.504 & 0.232 & 0.344 & -0.154 \\
\hline X4.2 & 0.774 & 0.610 & 0.603 & 0.464 & 0.909 & 0.629 & 0.673 & 0.479 & 0.504 & 0.232 & 0.344 & -0.154 \\
\hline X4.3 & 0.814 & 0.693 & 0.626 & 0.505 & 0.913 & 0.703 & 0.682 & 0.504 & 0.592 & 0.356 & 0.470 & -0.142 \\
\hline X4.3 & 0.814 & 0.693 & 0.626 & 0.505 & 0.913 & 0.703 & 0.682 & 0.504 & 0.592 & 0.356 & 0.470 & -0.142 \\
\hline Y1.1 & 0.750 & 0.592 & 0.701 & 0.499 & 0.724 & 0.803 & 0.919 & 0.478 & 0.648 & 0.302 & 0.447 & -0.233 \\
\hline Y1.1 & 0.750 & 0.592 & 0.701 & 0.499 & 0.724 & 0.803 & 0.919 & 0.478 & 0.648 & 0.302 & 0.447 & -0.233 \\
\hline Y1.2 & 0.643 & 0.446 & 0.598 & 0.466 & 0.639 & 0.771 & 0.916 & 0.433 & 0.621 & 0.380 & 0.356 & -0.137 \\
\hline Y1.2 & 0.643 & 0.446 & 0.598 & 0.466 & 0.639 & 0.771 & 0.916 & 0.433 & 0.621 & 0.380 & 0.356 & -0.137 \\
\hline Y1.3 & 0.765 & 0.635 & 0.749 & 0.506 & 0.681 & 0.840 & 0.936 & 0.442 & 0.728 & 0.338 & 0.479 & -0.188 \\
\hline Y1.3 & 0.765 & 0.635 & 0.749 & 0.506 & 0.681 & 0.840 & 0.936 & 0.442 & 0.728 & 0.338 & 0.479 & -0.188 \\
\hline Y2.1 & 0.553 & 0.385 & 0.424 & 0.496 & 0.560 & 0.680 & 0.511 & 0.927 & 0.440 & 0.426 & 0.515 & -0.189 \\
\hline Y2.1 & 0.553 & 0.385 & 0.424 & 0.496 & 0.560 & 0.680 & 0.511 & 0.927 & 0.440 & 0.426 & 0.515 & -0.189 \\
\hline Y2.2 & 0.462 & 0.410 & 0.324 & 0.380 & 0.461 & 0.601 & 0.376 & 0.906 & 0.426 & 0.361 & 0.414 & -0.184 \\
\hline Y2.2 & 0.462 & 0.410 & 0.324 & 0.380 & 0.461 & 0.601 & 0.376 & 0.906 & 0.426 & 0.361 & 0.414 & -0.184 \\
\hline Y3.1 & 0.593 & 0.622 & 0.559 & 0.411 & 0.439 & 0.628 & 0.422 & 0.466 & 0.644 & 0.339 & 0.428 & -0.318 \\
\hline Y3.1 & 0.593 & 0.622 & 0.559 & 0.411 & 0.439 & 0.628 & 0.422 & 0.466 & 0.644 & 0.339 & 0.428 & -0.318 \\
\hline Y3.2 & 0.603 & 0.524 & 0.574 & 0.465 & 0.482 & 0.764 & 0.617 & 0.413 & 0.868 & 0.302 & 0.459 & -0.107 \\
\hline Y3.2 & 0.603 & 0.524 & 0.574 & 0.465 & 0.482 & 0.764 & 0.617 & 0.413 & 0.868 & 0.302 & 0.459 & -0.107 \\
\hline Y3.3 & 0.693 & 0.617 & 0.670 & 0.486 & 0.573 & 0.809 & 0.679 & 0.350 & 0.910 & 0.330 & 0.560 & -0.137 \\
\hline Y3.3 & 0.693 & 0.617 & 0.670 & 0.486 & 0.573 & 0.809 & 0.679 & 0.350 & 0.910 & 0.330 & 0.560 & -0.137 \\
\hline Y3.4 & 0.678 & 0.599 & 0.629 & 0.481 & 0.586 & 0.826 & 0.682 & 0.386 & 0.917 & 0.394 & 0.566 & -0.117 \\
\hline Y3.4 & 0.678 & 0.599 & 0.629 & 0.481 & 0.586 & 0.826 & 0.682 & 0.386 & 0.917 & 0.394 & 0.566 & -0.117 \\
\hline Y4.1 & 0.417 & 0.363 & 0.353 & 0.354 & 0.350 & 0.554 & 0.367 & 0.431 & 0.404 & 1.000 & 0.446 & -0.089 \\
\hline Y4.1 & 0.417 & 0.363 & 0.353 & 0.354 & 0.350 & 0.554 & 0.367 & 0.431 & 0.404 & 1.000 & 0.446 & -0.089 \\
\hline Y5.1 & 0.589 & 0.559 & 0.514 & 0.502 & 0.447 & 0.710 & 0.464 & 0.510 & 0.601 & 0.446 & 1.000 & -0.219 \\
\hline Y5.1 & 0.589 & 0.559 & 0.514 & 0.502 & 0.447 & 0.710 & 0.464 & 0.510 & 0.601 & 0.446 & 1.000 & -0.219 \\
\hline
\end{tabular}


The Effect of Halal-Labelled Food Awareness Towards Purchase Intention Among Urban Muslims (Study of Indonesian Students in Japan)

\begin{tabular}{|c|c|c|c|c|c|c|c|c|c|c|c|c|}
\hline & $\mathbf{X}$ & X1 & $\mathrm{X} 2$ & $\mathrm{X3}$ & $\mathrm{X} 4$ & $\mathbf{Y}$ & Y1 & Y2 & Y3 & Y4 & Y5 & Y6 \\
\hline Y6.1 & -0.239 & -0.194 & -0.284 & -0.194 & -0.140 & -0.287 & -0.202 & -0.203 & -0.191 & -0.089 & -0.219 & 1.000 \\
\hline Y6.1 & -0.239 & -0.194 & -0.284 & -0.194 & -0.140 & -0.287 & -0.202 & -0.203 & -0.191 & -0.089 & -0.219 & 1.000 \\
\hline
\end{tabular}

\section{Average Variance Extracted (AVE)}

According to the (Urbach \& Ahlemann (2010: 21) the value of AVE should be above 0.5. To determining whether the data is valid or not in discrimination validity, the condition that has to be met is Root square of AVE > correlation between LVs (FORNELL, Claes; LARCKER, David F. 1981). The AVE generated from this research shows only one latent variable that has an AVE value below 0.5. However, it is considered to be used in the model, according to Bagozzi (1998) if the AVE value is less than 0.5 it still can be used unless the value is lower than 0.4 then it should be eliminated from construct.

Table 5 AVE Analysis

\begin{tabular}{cccc}
\hline Variable & AVE & AVE Root & $\begin{array}{c}\text { Test Criteria } \\
\mathbf{>} \mathbf{0 . 5}\end{array}$ \\
\hline X & 0.475 & 0.689 & Valid \\
X1 & 0.633 & 0.795 & Valid \\
X2 & 0.618 & 0.786 & Valid \\
X3 & 0.583 & 0.764 & Valid \\
X4 & 0.845 & 0.919 & Valid \\
Y & 0.498 & 0.706 & Valid \\
Y1 & 0.853 & 0.924 & Valid \\
Y2 & 0.840 & 0.917 & Valid \\
Y3 & 0.709 & 0.842 & Valid \\
Y4 & 1.000 & 1.000 & Valid \\
Y5 & 1.000 & 1.000 & Valid \\
Y6 & 1.000 & 1.000 & Valid \\
\hline
\end{tabular}

\section{Reliability Test}

To measure result reliabilities, both composite reliability and Cronbach's alpha test were utilized. Composite reliability measures internal consistency and its value should be above 0.7 (Hair et al 2010). In this respect, results shown indicates that the composite reliability value for this research is reliable since the value fulfill the reliability criteria. These results are similar to Cronbach alpha's test, with minimal value of 0.7 most variable indicates a reliable result. 
AFEBI Islamic Finance and Economic Review (AIFER)

Vol.02 No.02, December 2017

Table 6 Composite Reliability Test Analysis

\begin{tabular}{ccc}
\hline Variable & Composite Reliability & $\begin{array}{c}\text { Test Criteria } \\
\mathbf{> 0 . 7}\end{array}$ \\
\hline X & 0.921 & Reliable \\
X1 & 0.834 & Reliable \\
X2 & 0.854 & Reliable \\
X3 & 0.846 & Reliable \\
X4 & 0.942 & Reliable \\
Y & 0.908 & Reliable \\
Y1 & 0.946 & Reliable \\
Y2 & 0.913 & Reliable \\
Y3 & 0.906 & Reliable \\
Y4 & 1.000 & Reliable \\
Y5 & 1.000 & Reliable \\
Y6 & 1.000 & Reliable \\
\hline
\end{tabular}

Table 7 Cronbachs Alpha Test Analysis

\begin{tabular}{ccc}
\hline Variable & Cronbachs Alpha & $\begin{array}{c}\text { Test Criteria } \\
\mathbf{~ 0 . 7}\end{array}$ \\
\hline X & 0.904 & Reliable \\
X1 & 0.711 & Reliable \\
X2 & 0.763 & Reliable \\
X3 & 0.760 & Reliable \\
X4 & 0.908 & Reliable \\
Y & 0.877 & Reliable \\
Y1 & 0.914 & Reliable \\
Y2 & 0.811 & Reliable \\
Y3 & 0.856 & Reliable \\
Y4 & 1.000 & Reliable \\
Y5 & 1.000 & Reliable \\
Y6 & 1.000 & Reliable \\
\hline
\end{tabular}

\section{Hypothesis Test}

Hypothesis test was conducted by looking at the results of data processing PLS on the Path Coefficients. The Table 8 shows that Halal-labelled food Awareness (X) has a significant effect on Halal-labelled food Purchase Intention (Y) with a coefficient of 0.847 and t-count of 24.859 (24.859> 1.96). Referring to the chapter three to determine whether the hypothesis could be rejected or accepted, we used t-count and t-table as the provision below:

The significance level $\alpha=5 \%$, with the degree of freedom (d.f) $=n-1$, hence:

$\mathrm{H} 0$ is rejected if tcount $>$ ttable or tcount $<-$ ttable

$\mathrm{H} 1$ cannot be rejected if -ttable $\leq$ tcount $\leq$ ttable 
In short, we found that t-table value is lower than t-count (24.859> 1.96) hence $\mathrm{H} 0$ for this hypothesis is rejected and so the statement $\mathrm{H} 0$ "There is no significant influence of halal food awareness on halal food purchase intention" is rejected.

Table 8 Hypothesis Test

\begin{tabular}{lcccc}
\hline $\begin{array}{c}\text { Relationship } \\
\text { Between Variables }\end{array}$ & $\begin{array}{c}\text { Original } \\
\text { Sample (O) }\end{array}$ & t- Statistics & HO & Conclusion \\
\hline $\begin{array}{l}\text { Halal-labelled food } \\
\text { Awareness (X) } \rightarrow\end{array}$ & & & & \\
Halal- labelled food & 0.847 & 24.859 & Rejected & Significant \\
$\begin{array}{l}\text { Purchase Intention } \\
(Y)\end{array}$ & & & \\
\hline
\end{tabular}

\section{DISCUSSION Inner model}

A score of 24.8 from Halal-labelled food awareness (X latent variable) to Halal-labelled food purchase intention (Y latent var) means that in every increasing of $\mathrm{X}$ variable affect (increase) the $\mathrm{Y}$ variable, in other words the more people aware of halal-labelled food the higher their intention to purchase halal-labelled food (standard acceptance score: value $>1.96)$.

Religious belief variable (X1 latent variable) correlation score with halallabelled food awareness ( $\mathrm{X}$ latent variable) is 26.6 which also indicates that Religious belief affect halal-labelled food awareness and for every increase of X1 will significantly affect $\mathrm{X}$ variables (The more conformity level of people belief towards their religion their awareness of halal food is higher).

Halal certification variable (X2 latent variable) is significantly correlated with halal-labelled food awareness (X latent variable) with value more than 1.96 which also indicates that halal certification affect halal-labelled food awareness and for every increase of $\mathrm{X} 2$ will significantly affect $\mathrm{X}$ variables (The higher their knowledge about halal certification the higher their awareness towards halal food).

The X3 latent variable (Exposure variable) score towards X latent variable (Halal-labelled food awareness) is 16.7 which also higher than 1.96. This result means that exposure is also affecting halal-labelled food awareness and the higher or the more people exposed to halal food the higher their awareness would be.

The X4 latent variable (Health reason) score towards X latent variable (Halal-labelled food awareness) is 23.8 which also higher than 1.96. This result means that Health reason is also affecting halal-labelled food awareness and the more they trust that halal food is a healthy food the higher their awareness toward halal-labelled food.

The Y1 latent variable (Attitude toward halal food variable) score towards Y latent variable (Halal-labelled food purchase intention) is 26.2 which is higher than the required score/value (1.96). This result means that halal-labelled food purchase intention was formed by the attitude towards halal food and significantly 
correlated. This result also implies that the more positive someone's attitude toward halal food the higher chance to purchase halal-labelled food.

The Y2 latent variable (Subjective norm variable) score towards Y latent variable (Halal-labelled food purchase intention) is 8.94 which is higher than the required score/value (1.96). This result means that halal-labelled food purchase intention was formed by the subjective norm and significantly correlated. This result also implies that the more people engaged to the social expectation around their community (subjective norm) the more likely they will purchase halallabelled food.

PBC variable (Y3 latent variable) correlation score with halal-labelled food Purchase intention (Y latent variable) is 43.5 which also indicates that halallabelled food purchase intention affect PBC and for every increase of halal-labelled food purchase intention will significantly affect PBC variables (The higher someone willingness to purchase halal-labelled food, the better perceive behavior control).

Habit variable (Y4 latent variable) correlation score with halal-labelled food Purchase intention (Y latent variable) is 5.59 which also indicates that halallabelled food purchase intention affect habit and for every increase of halallabelled food purchase intention will significantly affect habit variables (Habit is measuring the automation process of purchasing halal food, the higher score on habit means that buying halal food is a process that does not need much consideration or the higher habit score indicates the more likely people would purchase halal food).

SI (Self-identity) variable (Y5 latent variable) correlation score with halal-labelled food Purchase intention (Y latent variable) is 10.24 which also indicates that halal-labelled food purchase intention affect SI and for every increase of halal-labelled food purchase intention will significantly affect SI variables (The higher score from Halal-labelled purchase intention indicate a more confident their SI as a Muslim).

DA (Diet Acculturation) variable (Y6 latent variable) correlation score with halal-labelled food Purchase intention (Y latent variable) is 2.10 for DA this is a different case since DA measures how acculturated the diet of migrated people. The higher DA score does not always mean they consume or purchase halallabelled food and vice versa. So, the correlation between DA and Halal-labelled purchase intention is low or not too correlated.

\section{Outer Model \\ X1 Variables}

$>\mathrm{X} 1.1$ variables manifest/indicators (obedience level) shows how much it relates with X1 latent variable (religious belief). From the analysis we found that the score of $\mathrm{X} 1.1$ to $\mathrm{X} 1$ is 0.587 . This result means that the indicator is valid to be used as an indicator. Hence, we could interpret the result as the higher obedience level the higher religious belief would be.

> X1.2 variables manifest/indicators (commitment not to eat non halal-labelled food) shows how much it relates with X1 latent variable (religious belief). From the analysis we found that the score of X1.2 to X1 is 0.894 . This result means that the indicator is valid to be used as an indicator. This result also implies that the higher their commitment level to not eat non-halal-labelled food, the higher their religious belief. 
> X1.3 variables manifest/indicators (belief of consequences of eating non halal food) shows how much it relates with X1 latent variable (religious belief). From the analysis we found that the score of X1.3 to X1 is 0.868 . This result means that the indicator is valid to be used as an indicator. This result also implies that the more people believe that the consequences of eating non-halal food does exist, the more religious they become.

\section{X2 Variables}

- Halal certification knowledge variable (X2.1 variable manifest) is correlated with Halal certification variable (X2 latent variable) with value of 0.36 which still higher than the minimum criteria. This result also indicates that halal certification knowledge affects Halal certification and for every increase of X2.1 will significantly affect X2 variables (The higher their knowledge about halal food the more proficient they were to distinguish halal food with nonhalal food).

- Halal certification urgency variable (X2.2 variable manifest) is significantly correlated with Halal certification/logo (X2 latent variable) with value of 0.878 . It indicates that the halal certification urgency affects Halal certification variable and for every increase of X2.2 will significantly affect X2 variable (The more they think that halal food certification is urgent the more their awareness toward halal certification increase).

$>$ Halal certification importance variable manifest/indicators (X2.3 variable manifest) is significantly correlated with Halal certification/logo (X2 latent variable) with value of 0.94 . It indicates that the halal certification importance affect Halal certification variable and for every increase of X2.3 will significantly affect $\mathrm{X} 2$ variables (The more they think that halal food certification is important the more their awareness toward halal certification increase).

> Halal product attraction variable manifest/indicators (X2.4 variable manifest) is significantly correlated with Halal certification/logo (X2 latent variable) with value of 0.84 . It indicates that the halal product attraction affecting Halal certification variable and for every increase of X2.4 will significantly affect $\mathrm{X} 2$ variables (The more they think that halal food is attractive the more their awareness toward halal certification increase).

\section{X3 Variables}

- Halal-labelled food socialization variable (X3.1 variable manifestation) correlation score with Exposure (X3 latent variable) is 0,61 which indicates that Halal-labelled food socialization affects Exposure and for every increase of Halal-labelled food socialization will affect Exposure variables (The more someone get information about halal food the more exposed they were).

$>$ Access of information to halal-labelled food variable's (X3.2 variable manifestation) correlation score with Exposure (X3 latent variable) is 0,68 which indicates that access of information to halal-labelled food variable affects Exposure and for every increase of access of information to halallabelled food socialization will affect Exposure variables (The more convenience access to halal food will increase people exposure to halal food).

> Family variable's (X3.3 variable manifestation) correlation score with Exposure (X3 latent variable) is 0,68 which indicates that family variable affects Exposure and for every increase of score of family variable will affect 
Exposure variables (The greater the role of the family to introduce or accustom halal food as daily diet the more exposed they are to halal food).

> Friend variable's (X3.4 variable manifestation) correlation score with Exposure (X3 latent variable) is 0,87 which indicates that friend variable affects Exposure and for every increase of score of friend variable will affect Exposure variables (The greater the role of friend to introduce or accustom halal food as daily diet the more exposed they are to halal food).

\section{X4 Variables}

$>\quad$ Healthy option food variable's (X4.1 variable manifestation) correlation score with Health reasons (X4 latent variable) is 0,935 which indicates that Healthy option food variable affects Health Reason and for every increase of score of healthy option food variable will affect health reasons variables (The more they believe halal food is a healthy option food the more aware they are towards halal food as their healthy option).

> Hygiene option food variable's (X4.2 variable manifestation) correlation score with Health reasons (X4 latent variable) is 0,909 which indicates that Hygiene option food variable affects Health Reason and for every increase of score of hygiene option food variable will affect health reasons variables (The more they believe halal food is a hygiene option food the more aware they are towards halal food as their healthy option).

> Disease prevention variable's (X4.3 variable manifestation) correlation score with Health reasons (X4 latent variable) is 0,913 which indicates that Disease prevention variable affects Health Reason and for every increase of score of Disease prevention variable will affect health reasons variables (The more they believe halal food is able to prevent disease the more aware they are towards halal food as their healthy option).

\section{Y1 Variables}

> Interest to consume halal-labelled food variable's (Y1.1 variable manifestation) correlation score with Attitude toward halal food (Y1 latent variable) is 0.919 which indicates that Interest to consume halal-labelled food variable affects Attitude towards halal food and for every increase of score of Interest to consume halal-labelled food variable will affect Attitude toward halal food variables (The more they interest to consume halal food the better their attitude towards halal food).

- Favorable/unfavorable decision to consume halal food variable's (Y1.2 variable manifestation) correlation score with Attitude toward halal food (Y1 latent variable) is 0.916 which indicates that favorable/unfavorable decision to consume halal food variable affects Health Reason and for every increase of score of Favorable/unfavorable decision to consume halal food variable will affect Attitude toward halal food variables (The more they satisfy for consuming halal food the better their attitude towards halal food).

> Right/wrong decision to buy halal food variable's (Y1.3 variable manifestation) correlation score with Attitude toward halal food (Y1 latent variable) is 0.936 which indicates that Right/wrong decision to buy halal food variable affects Attitude towards halal food and for every increase of score of Right/wrong decision to consume halal food variable will affect Attitude toward halal food variables (The more they think that consuming halal food is the right decision the better their attitude towards halal food will be). 


\section{Y2 Variables}

> Motivation to comply variable's (Y2.1 variable manifestation) correlation score with Subjective Norm (Y2 latent variable) is 0.927 which indicates that Motivation to comply variable affects Subjective norm and for every increase of score of motivation to comply variable will affect Subjective norm variables (The higher their motivation to comply with their surroundings the better their subjective norm).

$>$ Social perspective variable's (Y2.2 variable manifestation) correlation score with Subjective Norm (Y2 latent variable) is 0.906 which indicates that Social perspective variable affects Subjective norm and for every increase of score of Social perspective variable will affect Subjective norm variables (The better their social perspective the better their subjective norm).

\section{Y3 Variables}

- Ability (financially) to purchase halal food variable's (Y3.1 variable manifestation) correlation score with PBC (Y3 latent variable) is 0.644 which indicates that Ability (financially) to purchase halal food variable affects $\mathrm{PBC}$ and for every increase of score of Ability (financially) to purchase halal food variable will affect PBC variables (The better someone's ability to purchase halal food will make people have more control for their behavior).

> Knowledge to purchase halal food variable's (Y3.2 variable manifestation) correlation score with PBC (Y3 latent variable) is 0.868 which indicates that Knowledge to purchase halal food variable affects PBC and for every increase of score of knowledge to purchase halal food variable will affect PBC variables (The better someone's knowledge to purchase halal food will make people have more control for their behavior).

$>$ Ability to consume halal food variable's (Y3.3 variable manifestation) correlation score with PBC (Y3 latent variable) is 0.910 which indicates that Ability to consume halal food variable affects $\mathrm{PBC}$ and for every increase of score of Ability to consume halal food variable will affect $\mathrm{PBC}$ variables (The better someone's ability to consume halal food will make people have more control for their behavior).

> Knowledge to consume halal food variable's (Y3.4 variable manifestation) correlation score with PBC (Y3 latent variable) is 0.917 which indicates that Knowledge to consume halal food variable affects PBC and for every increase of score of knowledge to consume halal food variable will affect PBC variables (The better someone's knowledge to consume halal food will make people have more control for their behavior).

\section{Y4 Variables}

$>$ Likeliness to purchase halal food variable's (Y4.1 variable manifestation) correlation score with Habit (Y4 latent variable) is 1 which indicates that Likeliness to purchase halal food variable affects Habit and for every increase of score of Likeliness to purchase halal food variable will affect Habit variables (The more likeliness someone purchase halal food without much consideration the more people think that purchasing halal food as an automatic process/as a habit).

\section{Y5 Variables}

> Self-identification variable's (Y5.1 variable manifestation) correlation score with SI (Y5 latent variable) is 1 which indicates that Self-identification variable affects SI and for every increase of score of Self-identification 
variable will affect SI variables (The more someone's identifying themselves as a good muslim the better their self-identity).

\section{Y6 Variables}

$>$ Food type preferences variables (Y6.1 Variable manifestation) Correlation score with DA (Diet Acculturation) variable (Y6 latent variable) is 1.00 for DA, it indicates that Food type preferences variable affects DA and for every increase of score of Food type preferences variable will affect DA variables (The higher food type preferences score means samples prefer to eat the type of food/cuisine from where they live than from their hometown and means a better diet acculturation).

\section{CONCLUSION}

Based on the results of research and discussion that have been described in the previous chapter with the aim to know how the affect of halal-labelled food awareness toward the purchase intention, the conclusion can be gathered as follows:

1. Both halal-labelled food awareness and halal-labelled food purchase intention shows a result which can be categorized as very good.

2. Overall, people still stick to halal food even though they are living outside of Indonesia. Their halal-labeled awareness also categorized high compared to the same research in the different country. Halal certification knowledge has become the main source of awareness for halal food with a score of 30.52 .

3. After analyzing the result of SEM-PLS. Halal-labeled awareness and purchase intention are highly correlated which mean people may intend to buy halal food if they are aware of the halal product.

4. Halal-labelled food awareness towards halal-labelled food purchase intention shows the determinant value of coefficient and predictive relevance value as much as 0.718 or $71.8 \%$, which means that this research variable of $\mathrm{X}$ has a direct relevance to $\mathrm{Y}$ variable and is able to explain $71.8 \%$ of the research phenomena, while $28.2 \%$ were affected by other variables.

\section{References}

Aaker, D., Kumar, V., \& Leone, R. (2011). Marketing Research, 10thEdition. Wiley.

Adidaya, Y. A. (2016). Halal in Japan : History, Issues and Problems: The Effect of the "Halal Boom" Phenomenon on Japanese Society and Industry, University of Oslo, Oslo, Norway.

Ajzen, I. (1991). The theory of planned behavior. Orgnizational Behavior and Human Decision Processes, 50, 179-211. https://doi.org/10.1016/07495978(91)90020-T.

Alam, S. S., \& Sayuti, N. M. (2011). Applying the theory of Planned Behavior (TPB) in halal food purchasing. International Journal of Commerce and Management,21(1), 8- 20.

Ali, A., Xiaoling, G., Sherwani, M., Ali, A. (2017). Factors affecting Halal meat purchase intention - evidence from international Muslim students in 
The Effect of Halal-Labelled Food Awareness Towards Purchase Intention Among Urban Muslims (Study of Indonesian Students in Japan)

China. British Food Journal, 119(3). http://dx.doi.org/10.1108/BFJ-102016-0455.

Ambali, A. R., \& Bakar, A. N. (2014). People's Awareness on Halal Foods and Products: Potential Issues for Policy-Makers, Kuala Lumpur.

Bonne, K., \& Verbeke, W. (2007). Muslim consumer trust in halal meat status and control in Belgium. Science Direct, 79(1), 113-123.

Bonne, K., Vermeir, I., Bergeaud-Blackler, F., \& Verbeke, W. (2007). Determinants of halal meat consumption in France. British Food Journal, 100(5), 367-86.

Gozali, I. (2005). Aplikasi Analisis Multivariate dengan program SPSS, Edisi Ketiga. Semarang: Badan Penerbit Universitas Diponegoro.

Gozali, I., \& Latan, H. (2014). Partial Least Squares: Konsep, Teknik dan Aplikasi WarpPLS 4.0 (2nd). Semarang: BP UNDIP.

Kim, H. Y., \& Chung, J. E. (2011). Consumer purchase intention for organic personal care products. Journal of Consumer Marketing, 28(1), 40-47. https://doi.org/10.1108/07363761111101930.

Kotler, P., \& Kevin L.K. (2016) Marketing Management. 16th edition. Pearson, Prentice Hall.

Kotler, P., \& Armstrong G. (2015). Principle of Marketing 15th edition. Pearson, Prentice Hall.

Malhotra, N. K. (2010). Marketing Research: An Applied Orientation. Prentice Hall College.

Negy, C., \& Woods, D. J. (1992). The importance of acculturation in understanding research with Hispanic Americans. Hispanic Journal of Behavioural Science, 14, 224-47.

Randolph, G. (2003). Surgical anatomy of recurrent laryngeal nerve: surgery of the thyroid and parathyroid glands,( ed.) G. Randolph (2003), Elsevier, 30043.

Salman, F., \& Siddiqui, K. (2011). An exploratory study for measuring consumers awareness and perceptions towards halal food in Pakistan.

Satia, J. A., Patterson, R. E., Taylor, V. M., Cheney, C. L., Shiu-Thornton, S., Chitnarong, K., \& Kristal, A.R. (2000). Use of qualitative methods to study diet, acculturation, and health in Chinese-American women. Journal of American Dietetic Association, 1000, 934-40.

Schaefer, A., Parker, R. S., \& Haytko, D. (2011). Chinese and U.S. consumers' perceptions of the effectiveness of celebrity athlete endorsers. Journal of Management \& Marketing Research, 6, 1-9. https://doi.org/http://dx.doi.org/http://dx.doi.org/Article. 
Siregar, S. (2013). Metode Penelitian Kuantitatif. Jakarta: Kencana.

Strungă, A. C. (2014). Osgood's semantic differential: a review of the Romanian social sciences literature. Social Sciences and Education Research Review, University of Craiova, Romania.

Thomas Reuters. State of the global islamic economy report 2016/17, https://www.salaamgateway.com/en/story/ReportStateoftheGlobalIslami cEconomy201617SALAAM03102016111130/

Urbach, N., \& Ahlemann, F. (2010). Structural equation modeling in information systems research using partial least squares. JITTA: Journal of Information Technology Theory and Application, 11 (2), 5.

Yunus, N.S., Rashid, W.E., Ariffin, N.M, \& Rashid, N.M. (2014). Muslim's Purchase Intention towards Non-Muslim's Halal Packaged Food Manufacturer. Malaysia. 